\title{
Efficacy and safety of inhaled budesonide on prevention of acute mountain sickness during emergent ascent: a meta-analysis of randomized controlled trials
}

Gaurav Nepal ${ }^{1,2^{*}}$ (D), Jayant Kumar Yadav ${ }^{1,2}$, Jessica Holly Rehrig ${ }^{3}$, Niroj Bhandari ${ }^{4}$, Santosh Baniya ${ }^{1,2}$, Rakesh Ghimire ${ }^{1}$ and Narayan Mahotra ${ }^{1}$

\begin{abstract}
Background: Acute Mountain Sickness (AMS) is a pathophysiologic process that occurs in non-acclimated susceptible individuals rapidly ascending to high-altitude. Barometric pressure falls at high altitude and it translates to a decreased partial pressure of alveolar oxygen (PAO2) and arterial oxygen (PaO2). A gradual staged ascent with sufficient acclimatization can prevent AMS but emergent circumstances requiring exposure to rapid atmospheric pressure changes - such as for climbers, disaster or rescue team procedures, and military operations - establishes a need for effective prophylactic medications. This systematic review and meta-analysis aim to analyze the incidence of AMS during emergent ascent of non-acclimatized individuals receiving inhaled budesonide compared to placebo.

Methods: This current meta-analysis was conducted according to the guidance of the Preferred Reporting Items for Systematic Reviews and Meta-Analyses statement. We searched PubMed, Google Scholar and Embase for relevant studies. The efficacy of budesonide in reducing incidence of AMS was evaluated by calculating the pooled ORs and $95 \% \mathrm{Cls}$. The efficacy of budesonide in maintaining hemoglobin-oxygen saturation was evaluated by calculating standard mean difference (SMD) and 95\% confidence intervals.

Results: We found that at high altitude, inhaled budesonide was effective in reducing the incidence of mild AMS [OR: $0.37 ; 95 \% \mathrm{Cl}, 0.14$ to $0.9, p=0.042$ ] but was ineffective in reducing the incidence of severe AMS [OR: $0.46 ; 95 \%$ $\mathrm{Cl}, 0.14$ to $1.41, p=0.17$ ]. Inhaled budesonide was also effective in maintaining SpO2 (SMD: 0.47; 95\% Cl, 0.09 to $0.84, p=0.014$ ) at high altitude. However, it was not effective in maintaining or improving pulmonary function at high altitude. Systematic-review found no adverse effects of budesoide in the dose used for prophylaxis of AMS.

\footnotetext{
* Correspondence: gauravnepal@iom.edu.np

${ }^{1}$ Maharajgunj Medical Campus, Tribhuvan University Institute of Medicine,

Kathmandu, Nepal

${ }^{2}$ Mountain Medicine Society of Nepal, Kathmandu, Nepal

Full list of author information is available at the end of the article
}

\section{$\triangle B M C$}

(c) The Author(s). 2020 Open Access This article is licensed under a Creative Commons Attribution 4.0 International License, which permits use, sharing, adaptation, distribution and reproduction in any medium or format, as long as you give appropriate credit to the original author(s) and the source, provide a link to the Creative Commons licence, and indicate if changes were made. The images or other third party material in this article are included in the article's Creative Commons licence, unless indicated otherwise in a credit line to the material. If material is not included in the article's Creative Commons licence and your intended use is not permitted by statutory regulation or exceeds the permitted use, you will need to obtain permission directly from the copyright holder. To view a copy of this licence, visit http://creativecommons.org/licenses/by/4.0/. The Creative Commons Public Domain Dedication waiver (http://creativecommons.org/publicdomain/zero/1.0/) applies to the data made available in this article, unless otherwise stated in a credit line to the data. 
(Continued from previous page)

Conclusions: Our systematic review showed that prophylactic inhaled budesonide is effective in preventing mild AMS during emergency ascent but not effective in preventing severe AMS. Though statistically significant, authors recommend caution in interpretation of data and questions for further well designed randomized studies to evaluate the role of budesonide in prophylaxis of AMS during an emergent ascent.

Keywords: Acute Mountain sickness, Emergency ascent, High altitude illness, Inhaled budesonide, Budesonide, Disaster, Rescue, Meta-analysis

\section{Background}

Acute Mountain Sickness (AMS) is condition that occurs in non-acclimated individuals rapidly ascending to highaltitude. Above altitude of $2500 \mathrm{~m}$, the barometric pressure falls and the decreased barometric pressures translates to a decreased partial pressure of alveolar oxygen (PAO2) and arterial oxygen $(\mathrm{PaO} 2)$. This results in a hypoxic challenge to any individual ascending to higher altitude [1]. The normal compensatory response to hypobaric hypoxia is termed acclimatization, which begins within minutes of ascent but requires several weeks to complete [2, 3]. With rapid ascent, time for acclimatization is insufficient predisposing an individual to an increased risk of AMS [4]. The prevalence of AMS is correlated with increasing altitude and the risk is significant at altitude above $2500 \mathrm{~m}$. The prevalence of AMS at $2500 \mathrm{~m}$ is amongst 9 to $25 \%$ which increases to $75 \%$ at altitude above $4500 \mathrm{~m} \mathrm{[1].}$

The major determinants of AMS are the altitude attained, individual susceptibility, rate of ascent and degree of acclimatization [5]. AMS consists of nonspecific symptoms that occur within $6-12 \mathrm{~h}$ of arrival to altitude above $2500 \mathrm{~m}$ [6]. The symptoms are usually most pronounced after the first night spent at a new altitude and resolve spontaneously when appropriate measures are taken. High-altitude headache is a primary symptom of AMS and occurs with lassitude, malaise, nausea and dizziness $[6,7]$. No reliable genetic or physiologic markers are available to predict an individual's susceptibility to altitude illness which includes AMS, high altitude pulmonary edema (HAPE) or high altitude cerebral edema (HACE). A gradual staged ascent with sufficient acclimatization can prevent AMS. But emergent circumstances requiring exposure to rapid atmospheric pressure changes - such as for climbers, disaster or rescue team procedures, and military operations - establishes a need for effective prophylactic mediations. Currently, no gold-standard medication exists for emergency ascent.

Literature has shown acetazolamide, a carbonic anhydrase inhibitor, takes at least 1 day prior to ascent to its render beneficial effects, and oral dexamethasone, though effective in emergency situations, is associated with serious systemic side effects including gastrointestinal bleeding and hypothalamic-pituitaryadrenal (HPA) hormonal impairment [8-11]. More recently, budesonide (BUD), an inhaled glucocorticoid with fewer systemic side effects, has been considered a potential preventative measure in emergency ascent. Studies evaluating effectiveness of BUD as a prophylactic agent for AMS have yielded mixed results [12-16]. It has been hypothesized that signals arising from hypoxic lungs causes inflammation and oxidative damage and increase capillary permeability in lungs and brain, which is thought to be responsible for development of AMS. BUD probably suppresses this signal from hypoxic lungs to brain and prevent oxidative damage. Inhaled BUD has also been shown to blunt the response of aldosterone to renin elevation by suppression of Angiotensin Converting Enzyme, by preserving the integrity of pulmonary endothelial membrane [17].

This systemic review and meta-analysis aim to analyze the incidence of AMS during emergent ascent of nonacclimatized individuals receiving inhaled BUD compared to those receiving placebo. As no current meta-analysis exists, our results contribute robust evidence to medical literature regarding inhaled BUD's role as a prophylactic medication in emergency settings.

\section{Methods}

Our systematic review and meta-analysis of inhaled BUD as a prophylactic measurement for Acute Mountain Sickness used the PRISMA (Preferred Reporting Items for Systemic review and Meta-Analysis) statement in conjugation with the PRISMA checklist and flow diagram, for manuscript format development [18].

\section{Literature search}

The following databases served as sources for published studies prior to September 2018: PubMed, Google Scholar, Embase. Searches were conducted using the keywords "budesonide" or "inhaled budesonide" in combination with "high altitude", "acute mountain sickness", "emergent ascent", or "rapid ascent". Titles, abstracts, and full text were screened for study and report characteristics that matched eligibility criteria. Two independent reviewers screened and retrieved reports, with an 
additional investigator participating in review of study eligibility and inclusion in the meta-analysis. All potentially relevant reports were read independently by each author.

\section{Eligibility criteria}

Eligible studies were selected based on the criteria mentioned below:

\section{Study design}

All studies were peer-reviewed, double-blinded, randomized control trials (RCT) comparing a placebo control group to inhaled BUD treatment group in the setting of altitude ascent.

\section{Definition of Acute Mountain sickness}

All studies included were required to use the Lake Louise Symptom Score Questionnaire (LLS) to evaluate AMS. This is a subjective tool used to analyze the severity of symptoms reported during ascent to high altitude. Symptoms include high altitude headache, loss of appetite or nausea, dizziness, fatigue or lassitude and insomnia, each component score ranging from 0 to 3 . Score of $\geq 3$ was classified as mild AMS, 3-5 as moderate AMS and score $\geq 5$ as severe AMS [19]. The new Lake Louise score was introduced in 2018, which does not include sleep as its component and is not considered for the purpose of this metaanalysis.

\section{Participants}

All studies were required to include participants that were not acclimatized prior to participation.

\section{Dosage of budesonide}

All studies were required to report definitive dosing intervals and concentrations of inhaled BUD.

\section{Objective outcomes}

Included studies were to objectively assess the efficacy of BUD in rapid ascent through outcomes such as: incidence of AMS, pulmonary function tests, blood hemoglobin-oxygen saturation on pulse oximetry (SpO2), and adverse event rates.

\section{Data abstraction}

Data was manually extracted by investigators from eligible studies. The following variables were included: first author, type of design, site of study, year of publication, trial registration number, sample size, mean age and body mass index (BMI) of participants, incidence of AMS, pulse oximetry blood-oxygen saturation ( $\mathrm{SpO} 2$ ), pulmonary function (variable measures), starting altitude, maximum altitude, mode of ascent, ascent duration, drug dosages, inclusion and exclusion criteria used by each study.

\section{Outcome measures}

Our primary objective was to assess the efficacy of inhaled BUD on preventing AMS. Our primary outcome measure was incidence of mild and severe AMS [19]. The secondary outcomes were pulmonary function, $\mathrm{SpO} 2$ at maximum altitude and incidence of adverse effects.

\section{Assessment of methodological quality}

Studies were reviewed independently by two investigators using the guidelines provided by the Cochrane Collaboration tool for assessing risk of bias. All studies were assessed for random sequence generation, allocation concealment, blinding of participants, incomplete data outcome, and selective outcome reporting [20].

\section{Statistical analysis}

Statistical analysis was performed using Comprehensive Meta-Analysis software (CMA 3.3, Biostat, Englewood, NJ, 2014). Heterogeneity was estimated using Cochrane $\mathrm{Q}$ and $\mathrm{I}^{2}$ statistics. When significant heterogeneity was present, we selected the random-effects model to calculate the effects size, else fixed-effects model was used. Meta-analysis for the dichotomous data (AMS incidence) was performed using a random effects model with a treatment effect expressed as OR with $95 \%$ confidence intervals. The extracted data from the continuous data set was employed to obtain the standard mean difference (SMD) and 95\% confidence intervals using the random effects model. The offset between the studies was estimated using Begg's test and Egger's test.

\section{Results}

\section{Literature search and data extraction}

In total, 80 articles were identified after thorough database search. After exclusion of duplicates and those not meeting inclusion criteria, five studies were reviewed for data collection. Figure 1 shows the results of our literature search and selection. The characteristics of each included study discussed below are summarized in Tables 1 and 2.

\section{Study design}

All included studies were randomized, double-blind, placebo-controlled trials comparing inhaled BUD with other control groups including placebo for the prevention of AMS. However, there was considerable heterogeneity in terms of study design. Three trials were registered in China and sponsored by Chinese institutions and two were registered in the USA including one 


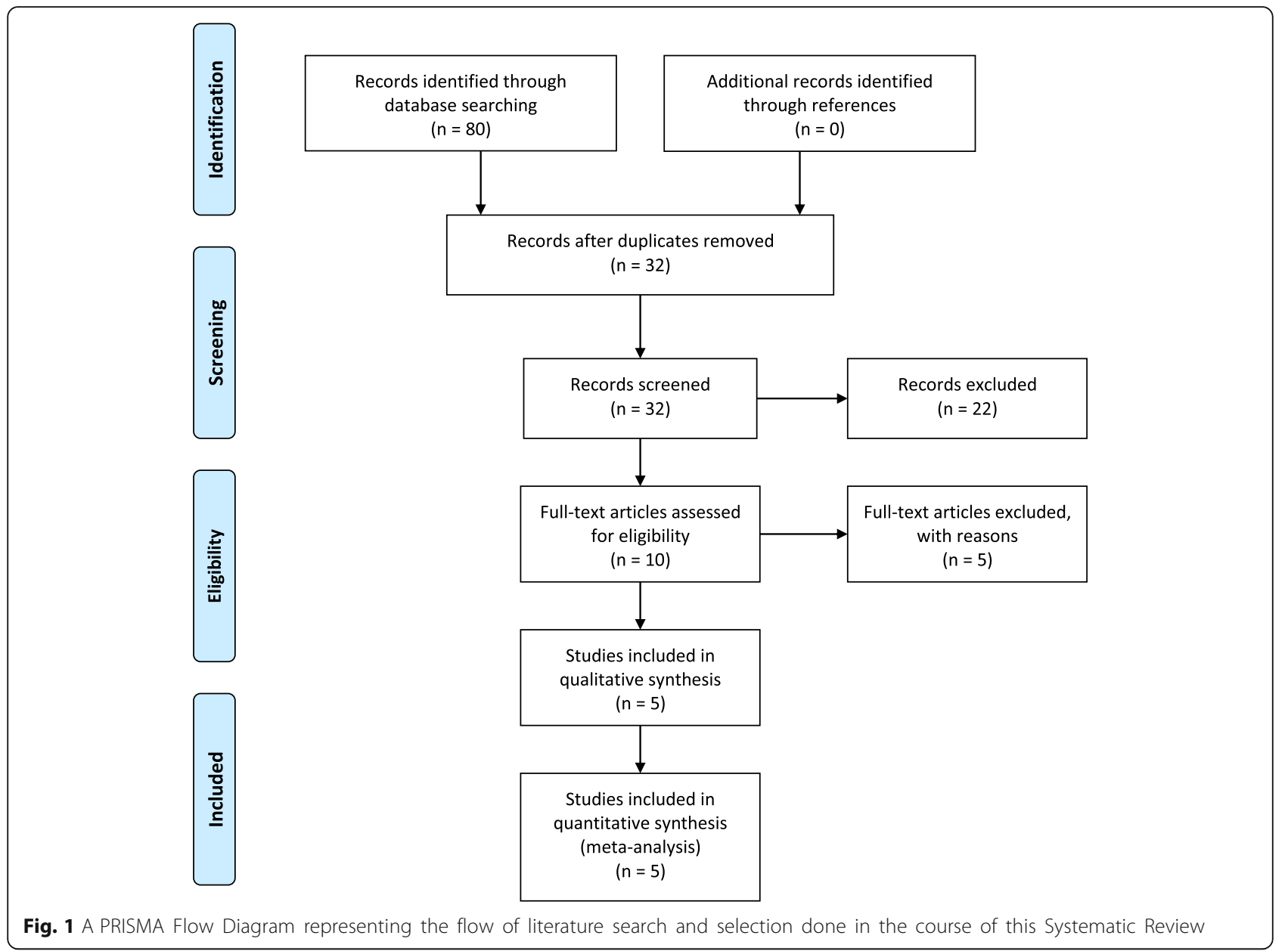

sponsored by Italian institution. Three studies were conducted at an altitude of more than $4000 \mathrm{~m}$. The starting height varied from $400 \mathrm{~m}$ to $2000 \mathrm{~m}$. The method of ascent was through a car, air, cable car, and hiking. Some of the studies used a combination of the aforementioned methods. The ascent duration ranged from $2.5 \mathrm{~h}$ to 5 days. The methodological characteristics of all the included studies based on the guidelines provided by the Cochrane Collaboration tool for assessing risk of bias are summarized in Fig. 2. "-" indicate high risk of bias, "+" indicate low risk of bias and "?" indicate unclear risk of bias.

\section{Treatment groups}

In all included RCTs, inhaled BUD was compared with several control groups, including the placebo group. In a study by Zheng et al., there were three treatment groups, viz. BUD, Dexamethasone (DEX) and placebo with 42,39 , and 43 subjects, respectively [12]. In a study by Chen et al., there were four treatment groups, BUD, Procaterol (PRO), budesonide / formoterol (B / F) and placebo with 20 subjects in each group [13]. In a study by Lipman et al. three treatment groups were included BUD, acetazolamide (ACZ) and placebo with 33, 35 and 35 subjects, respectively [15]. Berger et al. had two groups of BUD, $200 \mu \mathrm{g}$ and $800 \mu \mathrm{g}$, and the placebo group [14]. These groups included 16, 17, 17 subjects, respectively. A study by Wang et al. there were four groups, viz. Ipratropium bromide / salbutamol (I / S), BUD, salbutamol sulfate (SAL) and placebo with 31 subjects in BUD group and 30 in rest [16].

\section{Drugs and doses}

For comparison with the control groups, including the placebo, two different doses of BUD $(200 \mu \mathrm{g}$ bid. and $180 \mu \mathrm{g}$ bid.) were used. Berger et al. included two different doses of BUD i.e. $200 \mu \mathrm{g}$ and $800 \mu \mathrm{g}$ [14]. However, for uniformity and analysis we only included data of $200 \mu \mathrm{g}$ group. Doses of the control groups are shown in Table 2. 
Table 1 Key methodological characteristics of included studies

\begin{tabular}{|c|c|c|c|c|c|c|c|c|c|c|}
\hline Study & Year & Study site & $\begin{array}{l}\text { Trial } \\
\text { registration } \\
\text { number }\end{array}$ & $\begin{array}{l}\text { Treatment groups and } \\
\text { Sample size }\end{array}$ & $\begin{array}{l}\text { Maximum } \\
\text { Altitude }\end{array}$ & $\begin{array}{l}\text { Starting } \\
\text { altitude }\end{array}$ & $\begin{array}{l}\text { Ascent } \\
\text { mode }\end{array}$ & $\begin{array}{l}\text { Total } \\
\text { ascent } \\
\text { duration }\end{array}$ & AMS definition & $\begin{array}{l}\text { Severe AMS } \\
\text { definition }\end{array}$ \\
\hline $\begin{array}{l}\text { Zheng } \\
\text { et al. }\end{array}$ & 2014 & $\begin{array}{l}\text { Litang } \\
\text { County, } \\
\text { Sichuan } \\
\text { Province, } \\
\text { China }\end{array}$ & $\begin{array}{l}\text { ChiCTR-PRC- } \\
13003296\end{array}$ & $\begin{array}{l}\text { BUD }(n=42) \\
\text { DEX }(n=39) \\
\text { Placebo }(n=43)\end{array}$ & $4200 \mathrm{~m}$ & $650 \mathrm{~m}$ & Car & 4 days & $\begin{array}{l}\text { LLS } \geq 3 \text { with } \\
\text { headache }\end{array}$ & $L L S \geq 5$ \\
\hline $\begin{array}{l}\text { Chen } \\
\text { et al. }\end{array}$ & 2015 & $\begin{array}{l}\text { Lhasa, } \\
\text { Tibet, China }\end{array}$ & $\begin{array}{l}\text { ChiCTRPRC- } \\
12,002,748\end{array}$ & $\begin{array}{l}\text { BUD }(n=20) \\
\text { PRO }(n=20) \\
\text { B/F }(n=20) . \\
\text { Placebo }(n=20)\end{array}$ & $3700 m$ & $500 \mathrm{~m}$ & By air & $2.5 \mathrm{~h}$ & $\begin{array}{l}L L S \geq 3 \text { with } \\
\text { headache }\end{array}$ & $L L S \geq 5$ \\
\hline $\begin{array}{l}\text { Berger } \\
\text { et al. }\end{array}$ & 2017 & $\begin{array}{l}\text { Capanna } \\
\text { Regina } \\
\text { Margherita, } \\
\text { Monte } \\
\text { Rosa, Italy }\end{array}$ & NCT02811016 & $\begin{array}{l}\text { BUD } 200 \mu \mathrm{g}(n=16) \\
\text { BUD } 800 \mu \mathrm{g}(n=17) \\
\text { Placebo }(n=17)\end{array}$ & $4559 m$ & $1130 \mathrm{~m}$ & $\begin{array}{l}\text { Rope } \\
\text { way } \\
\text { and } \\
\text { Hiking }\end{array}$ & $20 \mathrm{~h}$ & $\begin{array}{l}\text { LLS } \geq 5 \text { plus AMS-C } \\
\text { score } \geq 0.70 \text {. } \\
\text { However, separate } \\
\text { analysis using LLS } \geq 3 \\
\text { with headache was } \\
\text { also done. We } \\
\text { included latter for } \\
\text { analysis. }\end{array}$ & $\begin{array}{l}\text { We included } \\
\text { LLS } \geq 5 \text { plus } \\
\text { AMS-C score } \geq \\
0.70 \text { for ana- } \\
\text { lysis of severe } \\
\text { AMS. }\end{array}$ \\
\hline $\begin{array}{l}\text { Lipman } \\
\text { et al. }\end{array}$ & 2017 & $\begin{array}{l}\text { White } \\
\text { Mountains } \\
\text { of } \\
\text { California, } \\
\text { USA }\end{array}$ & NCT02604173 & $\begin{array}{l}\text { Placebo }(n=35) \\
\text { AZ }(n=35) \\
\text { BUD }(n=33)\end{array}$ & $3810 m$ & $1240 \mathrm{~m}$ & $\begin{array}{l}\text { Car } \\
\text { and } \\
\text { Hiking }\end{array}$ & $4 \mathrm{~h}$ & $\begin{array}{l}L L S \geq 3 \text { with } \\
\text { headache }\end{array}$ & $L L S \geq 5$ \\
\hline $\begin{array}{l}\text { Wang } \\
\text { et al. }\end{array}$ & 2018 & $\begin{array}{l}\text { Litang } \\
\text { County, } \\
\text { Sichuan } \\
\text { Province, } \\
\text { China }\end{array}$ & $\begin{array}{l}\text { CHiCTR-PRC- } \\
16008441\end{array}$ & $\begin{array}{l}\text { I/S }(n=30) \\
\text { BUD }(n=31) \\
\text { SAL }(n=30) \\
\text { Placebo }(n=30)\end{array}$ & $4000 \mathrm{~m}$ & $2000 \mathrm{~m}$ & Car & 3 days & $\begin{array}{l}\text { LLS } \geq 3 \text { with } \\
\text { headache }\end{array}$ & $L L S \geq 5$ \\
\hline
\end{tabular}

Budesonide: $B U D$

Dexamethasone: DEX

Procaterol: PRO

Budesonide / formoterol: B / F

Acetazolamide: $A C Z$

Ipratropium bromide / salbutamol: I / S

Salbutamol sulfate: $S A L$

\section{Recruitment}

Zheng et al. recruited non-Tibetan healthy young men of age 18-35 years, residing in lowland [12]. Chen et al. recruited healthy, lowland residents of age 18 to 35 years, residing at or below $500 \mathrm{~m}$ altitude [13]. Lipman et al. recruited healthy, low landers residing below 1240 m $(4,100 \mathrm{ft}$.) who were able to complete moderately strenuous hike at high altitude [15]. Berger et al. recruited healthy, non-smoker, non-acclimatized lowlanders [14]. Wang et al. recruited healthy young male aged 18-28 years who lived a long term in $2000 \mathrm{~m}$ [16]. Exclusion criteria used during recruitment of the study subjects are tabulated in Table 2.

\section{End-point assessment}

Mild AMS: All studies used LLS $\geq 3$ with headache as mild AMS criteria. Meta-analysis for incidence of mild AMS was done using LLS $\geq 3$ with headache criteria.

Severe AMS: Berger et al. did not classify severe AMS in their study. However, all other studies used LLS $\geq 5$ as criteria for severe AMS. However Berger et al. used LLS $\geq 5$ with an AMS-C score $\geq 0.7$ for diagnosis of AMS in general. This criteria was considered equivalent to LLS $\geq 5$ criteria and meta-analysis was done for severe AMS.

Pulmonary function was evaluated by different methods. In a study by Zheng et al., forced vital capacity (FVC), FVC \%Pred. (percentage of the predicted value), forced expiratory volume in one second (FEV1), and FEV1\%Pred. were achieved with a portable spirometer. In a study by Chen et al., vital capacity (VC) and FEV1 were measured using a portable spirometer. Berger et al. measured FEV1 and FVC using a portable spirometer. Lipman et al. and Wang et al. did not measure pulmonary function at altitude.

\section{Outcomes}

Prevention of mild AMS

After performing meta-analysis, we found that at high altitude, inhaled BUD was effective in reducing the 
Table $\mathbf{2}$ Characteristics of patients and interventions in each included study

\begin{tabular}{|c|c|c|c|c|c|c|}
\hline Study & Study population & Exclusion criteria & Doses & $\begin{array}{l}\text { Drug administration } \\
\text { and assessment of } \\
\text { AMS }\end{array}$ & $\begin{array}{l}\text { Age in } \\
\text { years (mean } \pm \\
\text { SD) }\end{array}$ & $\mathrm{BMI}($ mean $\pm \mathrm{SD})$ \\
\hline $\begin{array}{l}\text { Zheng } \\
\text { et al. }\end{array}$ & $\begin{array}{l}\text { Non-Tibetan healthy } \\
\text { young male lowland } \\
\text { residents (18-35 } \\
\text { years old). }\end{array}$ & $\begin{array}{l}\text { HA (> } 2500 \mathrm{~m} \text { ) exposure } \\
\text { history in the past year; severe } \\
\text { organic diseases; } \\
\text { contraindications of } \\
\text { budesonide or } \\
\text { dexamethasone. }\end{array}$ & $\begin{array}{l}\text { Budesonide: } 200 \mu g \\
\text { per inhalation, bid. } \\
\text { Dexamethasone: } 4 \\
\text { mg, bid. } \\
\text { Placebo. }\end{array}$ & $\begin{array}{l}\text { Drugs started } 1 \text { day } \\
\text { before ascent and } \\
\text { continued for } 2 \text { days } \\
\text { after high altitude } \\
\text { exposure. } \\
\text { AMS assessed } 4 \text { days } \\
\text { after high altitude } \\
\text { exposure ( } 2 \text { days } \\
\text { after last inhalation) }\end{array}$ & $\begin{array}{l}\text { Budesonide: } \\
20.39 \pm 2.40 . \\
\text { Dexamethasone } \\
: 20.78 \pm 2.30 \\
\text { Placebo: } \\
20.52 \pm 2.35\end{array}$ & $\begin{array}{l}\text { Budesonide: } \\
21.32 \pm 2.28 . \\
\text { Dexamethasone: } \\
21.13 \pm 1.86 . \\
\text { Placebo } 20.95 \pm \\
1.95\end{array}$ \\
\hline $\begin{array}{l}\text { Chen } \\
\text { et al. }\end{array}$ & $\begin{array}{l}\text { Lowland residents at } \\
\text { or below } 500 \mathrm{~m} \text {, } \\
\text { healthy, and } 18 \text { to } \\
35 \text { years of age. }\end{array}$ & $\begin{array}{l}\text { HA (> } 2500 \mathrm{~m} \text { ) exposure } \\
\text { history in the past year or } \\
\text { organic diseases or } \\
\text { psychological or neurological } \\
\text { disorders. }\end{array}$ & $\begin{array}{l}\text { Budesonide: } 100 \mu \mathrm{g} \\
\text { per inhalation, two } \\
\text { inhalations bid. } \\
\text { Procaterol: } 25 \mu \mathrm{g} \text { bid. } \\
\text { Budesonide/ } \\
\text { formoterol: } \\
160 \mu \mathrm{g} \text { budesonide/ } \\
4.5 \mu \mathrm{g} \text { formoterol per } \\
\text { inhalation, one } \\
\text { inhalation, bid. } \\
\text { Placebo. }\end{array}$ & $\begin{array}{l}\text { Drugs started } 3 \text { days } \\
\text { before ascent and } \\
\text { stopped after high } \\
\text { altitude exposure. } \\
\text { AMS assessed } 1 \text { day } \\
\text { after high altitude } \\
\text { exposure (1 day after } \\
\text { last inhalation). }\end{array}$ & $\begin{array}{l}\text { Budesonide } \\
: 21.85 \pm 3.23 . \\
\text { Procaterol: } \\
20.30 \pm 2.03 . \\
\text { Budesonide/ } \\
\text { formoterol: } \\
20.60 \pm 2.76 . \\
\text { Placebo: } \\
21.65 \pm 3.31\end{array}$ & $\begin{array}{l}\text { Budesonide: } \\
20.98 \pm 2.21 . \\
\text { Procaterol: } \\
21.00 \pm 1.44 \text {. } \\
\text { Budesonide/ } \\
\text { formoterol: } \\
21.64 \pm 1.49 \text {. } \\
\text { Placebo: } 22.15 \pm \\
2.94 \text {. }\end{array}$ \\
\hline $\begin{array}{l}\text { Berger } \\
\text { et al. }\end{array}$ & $\begin{array}{l}\text { Healthy, non-smoker, } \\
\text { non-acclimatised } \\
\text { lowlanders were in- } \\
\text { cluded in the study }\end{array}$ & $\begin{array}{l}\text { Spent time at altitudes }>2000 \\
\mathrm{~m} \text { within the past } 4 \text { weeks } \\
\text { before the study, took any } \\
\text { regular medication }\end{array}$ & $\begin{array}{l}\text { Budesonide } 200 \mu \mathrm{g} \text { : } \\
\text { bid. } \\
\text { Budesonide } 800 \mu \mathrm{g} \text { : } \\
\text { bid. } \\
\text { Placebo. }\end{array}$ & $\begin{array}{l}\text { Drugs started } 1 \text { day } \\
\text { prior to ascent and } \\
\text { continued for } 4 \text { days } \\
\text { ( } 2 \text { days after high } \\
\text { altitude exposure). } \\
\text { AMS assessed on last } \\
\text { day of inhalation ( } 2 \\
\text { days after high } \\
\text { altitude exposure). }\end{array}$ & $\begin{array}{l}\text { Budesonide } \\
200 \mu \mathrm{g}: 38 \pm 11 \\
\text { Budesonide } \\
800 \mu \mathrm{g}: 38 \pm 11 \\
\text { Placebo: } 36 \pm \\
12 .\end{array}$ & $\begin{array}{l}\text { Budesonide } \\
200 \mu \mathrm{g}: 24.0 \pm \\
2.1 . \\
\text { Budesonide } \\
800 \mu \mathrm{g}: 22.5 \pm \\
2.2 \text {. } \\
\text { Placebo: } 22.8 \pm \\
2.5 \text {. }\end{array}$ \\
\hline $\begin{array}{l}\text { Lipman } \\
\text { et al. }\end{array}$ & $\begin{array}{l}\text { Healthy, low landers } \\
<1240 \mathrm{~m}(4,100 \mathrm{ft}), \\
\text { able to complete a } \\
\text { moderately strenuous } \\
\text { hike at high altitude }\end{array}$ & $\begin{array}{l}\text { Younger than } 18 \text { years old or } \\
\text { over } 65, \text { pregnant or } \\
\text { considered pregnant, living or } \\
\text { sleeping at an altitude of more } \\
\text { than } 1240 \mathrm{~m} \text { ( } 4,100 \mathrm{ft}) \text { last } \\
\text { week, taking diuretics, steroids, } \\
\text { acetazolamide or NSAIDs a } \\
\text { week before the study, allergy } \\
\text { to study drugs or a dangerous } \\
\text { condition, which did not allow } \\
\text { to travel at high altitude }\end{array}$ & $\begin{array}{l}\text { Placebo. } \\
\text { Acetazolamide: } 125 \\
\text { mg PO bid. } \\
\text { Budesonide: } 180 \mu \mathrm{\mu g} \\
\text { per inhalation bid. }\end{array}$ & $\begin{array}{l}\text { Drugs started on } \\
\text { morning of ascent } \\
\text { day and AMS } \\
\text { assessed on evening } \\
\text { after high altitude } \\
\text { exposure. }\end{array}$ & $\begin{array}{l}\text { Placebo: } 32 \pm 7 \\
\text { Acetazolamide: } \\
33 \pm 9 \text {. } \\
\text { Budesonide: } \\
33 \pm 10\end{array}$ & $\begin{array}{l}\text { Placebo: } 24 \pm 2.6 \text {. } \\
\text { Acetazolamide: } \\
24.1 \pm 1.93 \\
\text { Budesonide: } \\
22.7 \pm 2.1\end{array}$ \\
\hline $\begin{array}{l}\text { Wang } \\
\text { et al. }\end{array}$ & $\begin{array}{l}\text { Healthy young male } \\
\text { who lived a long } \\
\text { term in } 2000 \text { m (18- } \\
28 \text { years old). }\end{array}$ & $\begin{array}{l}\text { HA (> } 2500 \mathrm{~m} \text { ) exposure } \\
\text { history in the past year; severe } \\
\text { organic diseases or } \\
\text { psychological or neurological } \\
\text { disorders; contraindications of } \\
\text { study drugs; other unsuitable } \\
\text { conditions }\end{array}$ & $\begin{array}{l}\text { Ipratropium bromide/ } \\
\text { salbutamol: } 0.5 \mathrm{mg} \\
\text { ipratropium bromide/ } \\
3 \mathrm{mg} \text { salbutamol } \\
\text { sulfate per inhalation, } \\
\text { bid. } \\
\text { Budesonide: } 2.0 \mathrm{mg} \\
\text { per inhalation, bid. } \\
\text { Salbutamol sulfate: } \\
5.0 \mathrm{mg} \text { per inhalation, } \\
\text { bid. } \\
\text { Placebo. }\end{array}$ & $\begin{array}{l}\text { Drugs started on day } \\
\text { of ascent and } \\
\text { continued till high } \\
\text { altitude exposure ( } 3 \\
\text { days). } \\
\text { AMS assessed after } \\
3 \text { days of high } \\
\text { altitude exposure. }\end{array}$ & $\begin{array}{l}\text { Ipratropium } \\
\text { bromide/ } \\
\text { salbutamol: } \\
21.89 \pm 2.78 \text {. } \\
\text { Budesonide: } \\
21.35 \pm 3.05 \text {. } \\
\text { Salbutamol } \\
\text { sulfate: } 21.25 \pm \\
\text { 2.35. } \\
\text { Placebo: } \\
22.83 \pm 2.74 \text {. }\end{array}$ & $\begin{array}{l}\text { Ipratropium } \\
\text { bromide/ } \\
\text { salbutamol: } \\
21.55 \pm 1.31 . \\
\text { Budesonide: } \\
21.94 \pm 2.11 \\
\text { Salbutamol } \\
\text { sulfate: } 21.40 \pm \\
1.68 . \\
\text { Placebo: } 21.73 \pm \\
2.25 \text {. }\end{array}$ \\
\hline
\end{tabular}

incidence of mild AMS [OR: 0.37; 95\% CI, 0.14 to 0.9 , $p=0.042]$. There was significant heterogeneity between studies $\left(\mathrm{I}^{2}=64.49 \%\right)$. The forest plot of the result in random effects model is demonstrated in Fig. 3. There was no evidence of publication bias by Begg's test $(p=1)$ and Egger's test $(p=0.67)$. We performed subgroup analysis to estimate the effect of various subgroups on incidence of mild AMS. Inhaled BUD was effective in reducing the incidence of mild AMS in subgroup of studies done in China [OR: 0.24; $95 \% \mathrm{CI}, 0.13$ to $0.46, p=0.000, \mathrm{I}^{2}=0 \%$ ] but not in studies from Europe and USA [OR: 0.84; $95 \%$ CI, 0.11 to $\left.6.08, p=0.86, \mathrm{I}^{2}=44.7 \%\right]$. 


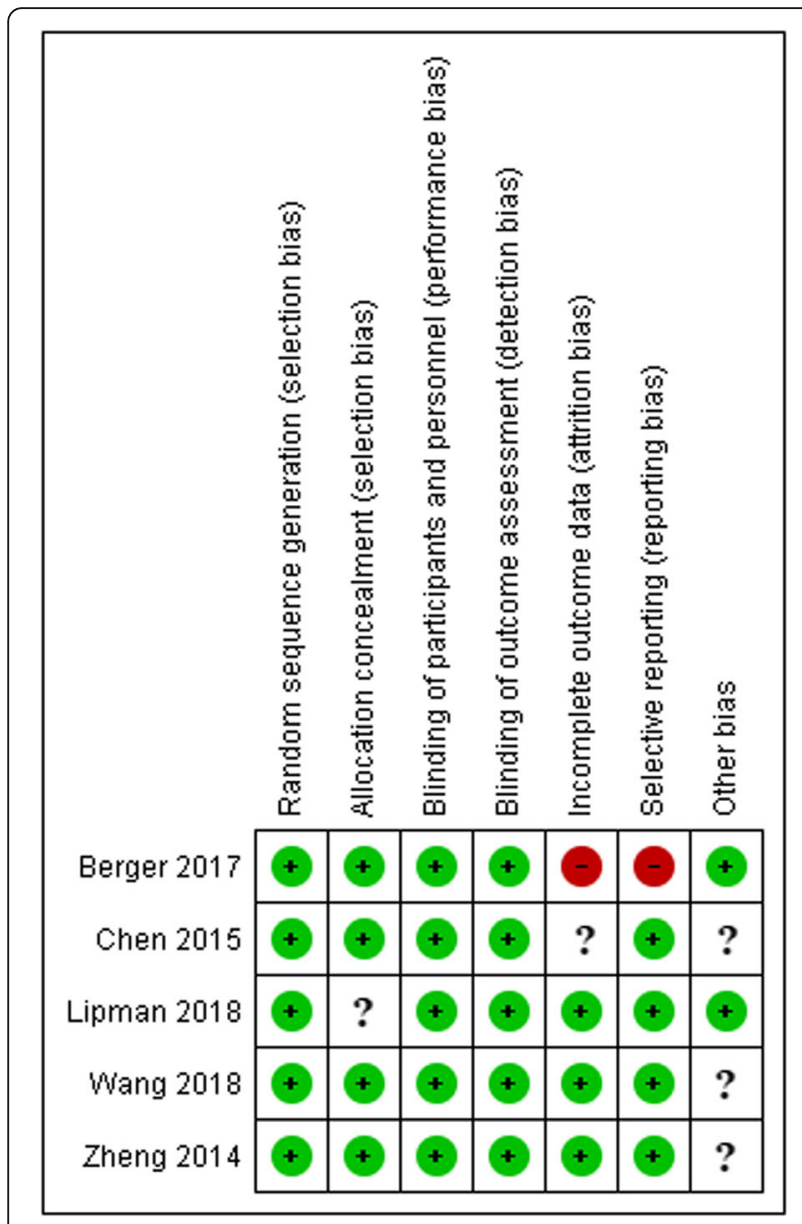

Fig. 2 Risk of bias graph. "-" indicate high risk of bias, "+" indicate low risk of bias and "?" indicate unclear risk of bias

\section{Prevention of severe AMS}

We found that, inhaled BUD was not effective in reducing the incidence of severe AMS [OR: 0.46; 95\% $\mathrm{CI}, 0.14$ to $1.41, p=0.17]$. There was significant heterogeneity between studies $\left(\mathrm{I}^{2}=61.39 \%\right)$. The Forest plot of the result in random effects model is demonstrated in Fig. 4. There was no evidence of publication bias by Begg's test $(p=0.22)$, and Egger's test $(p=0.4)$. On subgroup analysis, we found that Inhaled BUD was effective in reducing the incidence of severe AMS in subgroup of studies done in China [OR: 0.2; $95 \% \mathrm{CI}, 0.04$ to $0.96, p=0.04, \mathrm{I}^{2}=47.7 \%$ ] but not in studies from Europe and USA [OR: 1.05; 95\% CI, 0.48 to $\left.2.3, p=0.89, \mathrm{I}^{2}=0 \%\right]$.

\section{SpO2 and pulmonary function}

We found that inhaled BUD was effective in maintaining SpO2 (SMD: 0.47; 95\% CI, 0.09 to $0.84, p=$ $\left.0.014, \mathrm{I}^{2}=58.62 \%\right)$ at high altitude. Forest plot of the result in random-effects model is demonstrated in Fig. 5. There was no evidence of publication bias by Begg's test $(p=0.85)$ and Egger's test $(p=0.68)$. We found that inhaled BUD was effective in maintaining SpO2 (SMD: 0.643 ; 95\% CI, 0.09 to $1.18, p=0.02$, $\left.\mathrm{I}^{2}=68.39 \%\right)$ at high altitude in subgroup of studies done in China. However, it was ineffective in maintaining SpO2 (SMD: $0.218 ; 95 \% \mathrm{CI},-0.38$ to 0.82 , $\left.p=0.47, \mathrm{I}^{2}=52.87 \%\right)$ at high altitude in subgroup of studies done in Europe and USA.

Since all included studies used different methods to assess pulmonary function and some studies did not assess pulmonary function, we were unable to conduct a metaanalysis on this. In the study by Zheng et al., the spirometric parameters were similar among various study groups at sea level. In every group, FVC and FVC \%

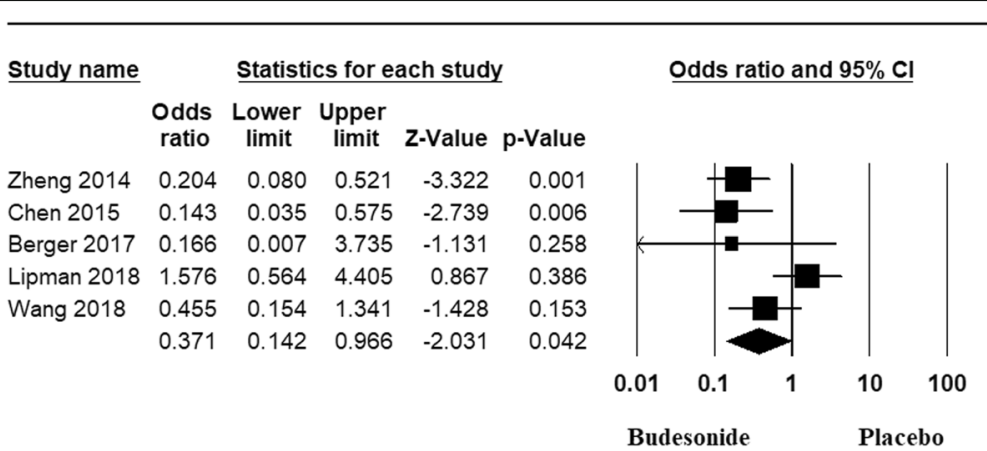

Fig. 3 Forest plot with 95\% Cl for incidence of AMS. The area of each square is proportional to the study's weight in the meta-analysis, while the diamond shows the pooled result. The horizontal lines through the square illustrate the length of the confidence interval. The width of the diamond serves the same purpose. The overall meta-analysed measure of effect is imaginary vertical line passing through diamond. If result estimates are located to the left, it means that the outcome of interest (incidence) occurred less frequently in the intervention group than in the control group 


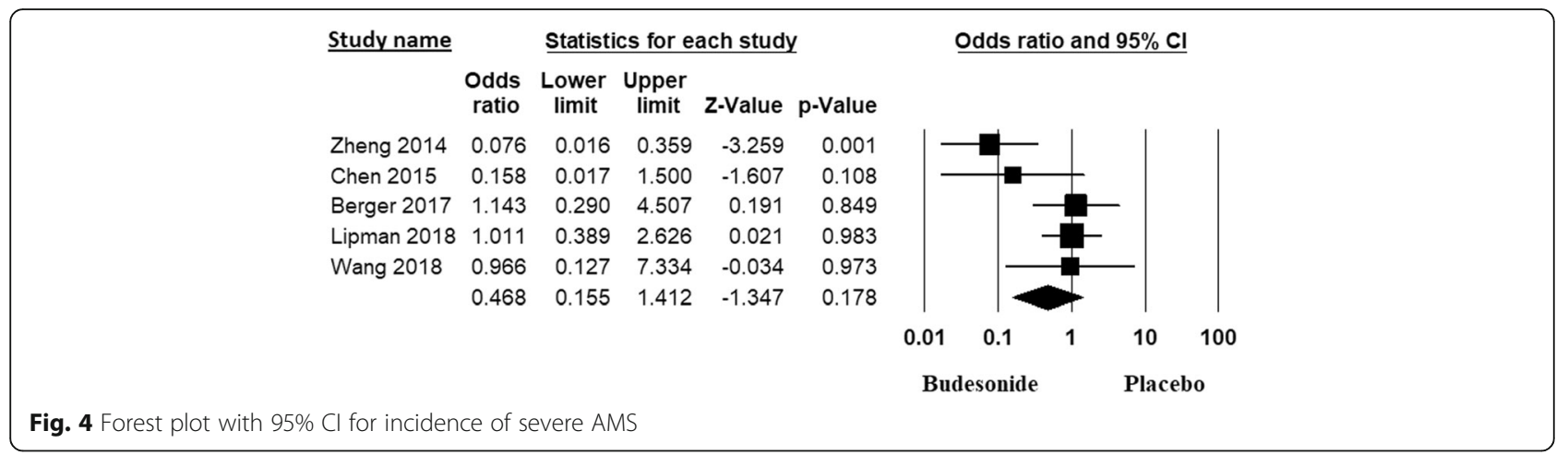

Pred. dropped after high-altitude exposure, while FEV1 and FEV1\% Pred. did not change significantly. The inhaled BUD group had significantly smaller degree of decrement ( $\triangle \mathrm{FVC}$ and $\triangle \mathrm{FVC} \%$ Pred.) than the placebo group (both $P<0.05$ ). In the study by Cheng et al., there were no significant differences in VC or FEV1 among the treatment groups at $20 \mathrm{~h}$ after exposure to high altitude. Further analysis also showed no differences between subjects with and without AMS in each group. Berger et al. showed that, FVC, FEV1, and the ratio between FEV1 and FVC were not different among groups at high altitude at any point of time. Based on these findings, it can be said that inhaled BUD is no better than placebo in preserving pulmonary function at high altitude.

\section{Adverse effects}

Zheng et al., Lipman et al., Cheng et al. and Wang et al. reported no adverse reactions related to the study drug in subjects from the inhaled BUD group. Berger et al. reported that plasma levels of adrenocorticotropic hormone and cortisol, as well as urine excretion of cortisol within $24 \mathrm{~h}$ did not differ between the studied groups, indicating that inhaled BUD did not suppress the hypothalamic-pituitary-adrenal axis. Therefore, inhaled BUD might not have any systemic effects.

\section{Discussion}

In this systematic review and meta-analysis, we critically appraised five randomized controlled trials for the effectiveness of inhaled BUD as a prophylactic agent for AMS during emergent ascent. At high altitude, BUD was found to be effective in reducing the incidence of mild AMS during emergent ascent. However, on subgroup analysis, inhaled BUD was effective in reducing the incidence of mild AMS in subgroup of studies done in China but not in studies from Europe and USA. A possible explanation is in the difference between method of ascent and total ascent duration. All three studies by Chinese colleagues used passive method of ascent by car $[12,16]$ or by air [13] and 2 out of 3 studies by Chinese colleagues had an ascent duration beyond $48 \mathrm{~h}[12,16]$. Another explanation could be the difference between mean ages of subjects included in the study. Studies from China had mean age of 20 [12] or $21 \mathrm{yr}[13,16]$.

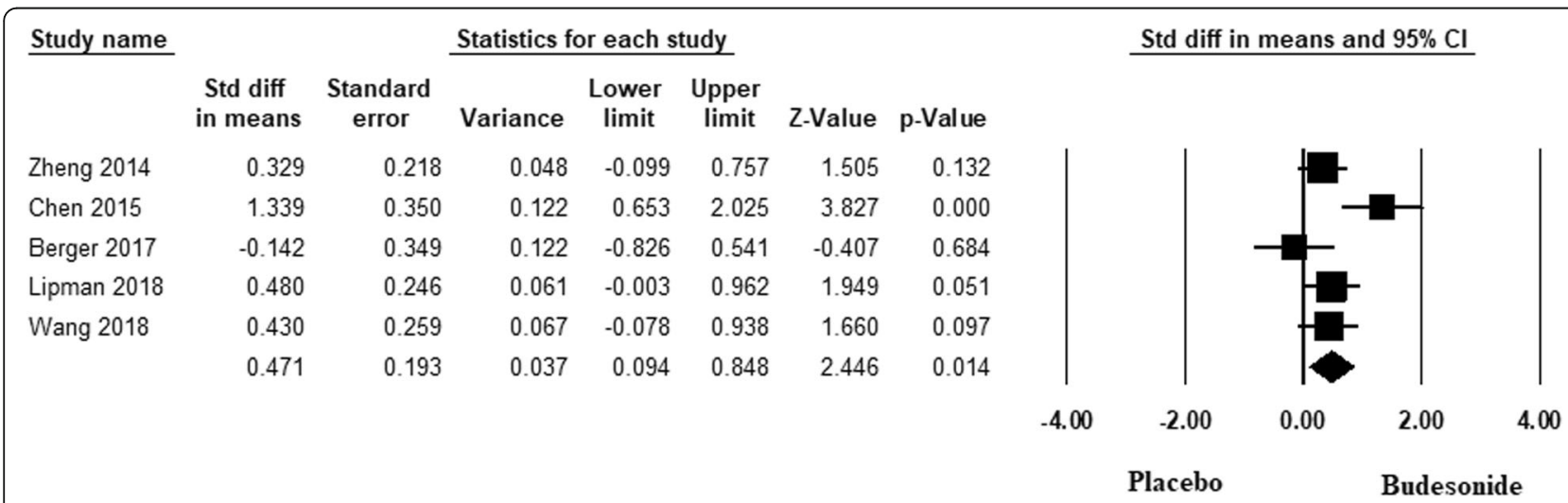

Fig. 5 Forest plot depicting the standardized mean difference (SMD) and its 95\% confidence interval for SpO2. The square shows the SMD for each study. The diamond at the bottom of the graph shows the average effect size of included studies 
However, the mean age in studies by Berger et al. and Lipman et al. were 38 and 33 years respectively $[14,15]$. Increasing age is associated with reduced plasma concentrations of budesonide at $20 \mathrm{~min}$ [21]. The lung matures by age 20-25 years, and thereafter aging is associated with progressive decline in lung function and further the airways receptors undergo functional changes with age that make them less responsive to medication [22]. We found that inhaled BUD was not effective in reducing the incidence of severe AMS. However, on subgroup analysis, inhaled BUD was effective in reducing the incidence of severe AMS in subgroup of studies done in China but not in studies from Europe and USA. This result can be explained by the same assumption mentioned above.

BUD is one of the most frequently prescribed inhaled corticosteroids worldwide that has been used in the long-term management of chronic obstructive pulmonary disease and asthma. Our systematic-review found that BUD is not effective in maintaining or improving pulmonary function. A possible explanation for this finding is that the observed decrease in pulmonary function is caused by a reduced effort due to fatigue or symptoms of AMS that may impair the maximum effort that is critical to adequate pulmonary function testing. $\mathrm{SpO} 2$ was significantly higher in BUD group than in the placebo group at high altitude, which indicate that inhalation of BUD have a significant effect on pulmonary gas exchange. However, significance was lost when subgroup analysis was done including studies done outside China.

Though there were many similarities among studies, including dosage of the study drug, size of the cohorts and AMS assessment tools, high level of heterogeneity was ubiquitous in all of our analyses. Taking help from the subgroup analyses, we tried to explore the source of heterogeneity in ours study. We found that heterogeneity might have been introduced because of the methodological or demographic differences among studies.

Fall in partial pressure of oxygen at altitude causes a low ventilatory drive, impaired gas exchange due to interstitial pulmonary edema, and increased metabolism ultimately causing hypoxemia and tissue hypoxia $[1,2]$. Hypoxemia results in an increase in cerebral blood flow, increase in vascular permeability through a higher oxidative stress or low-grade inflammation or increased expression of vascular endothelial growth factor (VEGF), venous outflow restriction, free radicals induced pump failure, lipid peroxidation, and destabilization of astrocyte membrane causing astrocyte swelling and hence causes cerebral edema [1, 2325]. Furthermore, there is activation of nociceptors in trigeminovascular system due to pressure or distortion through cerebral edema and also due to release of nociceptive chemicals $[1,3]$. Accordingly, drugs that mitigates cerebral edema, such as ACZ [26] or DEX $[27,28]$, are well tested and validated by various studies and are currently in use for prevention of AMS. However, ACZ is not considered effective for emergent ascent [11] and DEX have various systemic side effects [8-10]. Steroids like BUD seems to be a conceptually and clinically attractive option for AMS prevention. Accordingly, our meta-analysis of RCTs testing inhaled BUD for preventing AMS found that BUD is effective in preventing mild AMS during emergent ascent. But it was found to be ineffective in preventing severe AMS. However, authors recommend caution in interpretation of data as the weightage of studies done in China by Zheng and Wang et al. may have tilted the equation in favor of BUD contrary to studies elsewhere. The rate of ascent was very slow in Chinese studies, approximately 3-4 days allowing acclimatization and cannot be exactly considered as emergent ascent. Further, LLS score was taken after 4 days. LLS is highly subjective and authors believe that the result may have influenced by high incidence of AMS which may be attributed to fatigue and motion sickness following prolonged journey by car over a number of days. However, it suggests that BUD might be considered as prophylaxis of AMS if the ascent is slow and might be considered in patients who are allergic to ACZ.

This study has some limitations. First, some trials recruited a small number of patients in each treatment group. Second, most studies do not systematically describe adverse reactions, making it difficult to get a definitive conclusion about the incidence of these adverse events. Third, we were unable to compare different doses of BUD, so dose-related responses could not be found due to lack of data in the included studies. Fourth, the AMS diagnostic criteria among included studies were not uniform. Finally, LLS was recently revised in 2018 [29] and did not include insomnia as the standard for AMS. All studies included took place before 2018 .

\section{Conclusion}

Our systematic review showed that prophylactic inhaled BUD is effective in preventing mild AMS during emergency ascent but not effective in preventing severe AMS. Though statistically significant, authors recommend caution in interpretation of data as the weightage of studies done in China may have tilted the equation in favor of BUD contrary to studies elsewhere. The rate of ascent was slow and passive in Chinese studies and cannot be considered emergent ascent. This questions for further randomized studies to evaluate the role of BUD in prophylaxis of AMS in both emergent and slow ascents. 


\section{Abbreviations}

AMS: Acute mountain sickness; RCT: Randomized controlled trial; BMI: Body mass index; PRISMA: Preferred Reporting Items for Systematic Reviews and Meta-Analyses; BUD: Budesonide; DEX: Dexamethasone; PRO: Procaterol; B / F: Budesonide / formoterol; ACZ: Acetazolamide; SAL: Salbutamol sulfate; OR: Odds Ratio; SpO2: Arterial hemoglobin oxygen saturation; SMD: Standard mean difference; LLS: Lake Louise Symptom Score Questionnaire; FVC: Forced vital capacity; FEV1: Forced expiratory volume in one second; VC: Vital Capacity

\section{Acknowledgements}

None.

\section{Authors' contributions}

GN, JKY and JHR designed the study. GN, JHR and RG carried out literature search, review and selection. GN, RG, SB, NM and NB carried out the statistical analysis and drafted the manuscript. All authors were involved in revising the manuscript critically for important intellectual content. All authors read and approve the final manuscript.

\section{Funding}

No funding was received for this study.

\section{Availability of data and materials}

Not applicable.

\section{Ethics approval and consent to participate}

Not applicable.

\section{Consent for publication}

Not applicable.

\section{Competing interests}

None of the authors has any conflict of interest to disclose. We confirm that we have read the Journal's position on issues involved in ethical publication and affirm that this report is consistent with those guidelines.

\section{Author details}

${ }^{1}$ Maharajgunj Medical Campus, Tribhuvan University Institute of Medicine, Kathmandu, Nepal. ${ }^{2}$ Mountain Medicine Society of Nepal, Kathmandu, Nepal. ${ }^{3}$ University of New England College of Osteopathic Medicine, Biddeford, ME, USA. ${ }^{4}$ Kathmandu University School of Medical Sciences, Panauti, Nepal.

\section{Received: 29 September 2019 Accepted: 29 April 2020}

\section{Published online: 13 May 2020}

\section{References}

1. Luks AM, Swenson ER, Bärtsch P. Acute high-altitude sickness. Eur Respir Rev. 2017;26(143):160096. Available from:. https://doi.org/10.1183/16000617. 0096-2016.

2. West JB. Review The Physiologic Basis of High-Altitude Diseases; 2015. p 789-800.

3. Mehta SR, Chawla A, Kashyap AS. Acute mountain sickness, high altitude cerebral oedema, high altitude pulmonary oedema: the current concepts. Med J Armed Forces India. 2008;64(2):149-53. Available from:. https://doi. org/10.1016/S0377-1237(08)80062-7

4. Grocott M, Montgomery H, Vercueil A. High-altitude physiology and pathophysiology: implications and relevance for intensive care medicine. Crit Care. 2007;11(1):1-5.

5. Schommer K, Bärtsch P. Basic medical advice for travelers to high altitudes. Deutsches Ärzteblatt International. 2011;108(49):839.

6. Hackett PHRR. High-altitude illness. NEJM. 2001;345(2):107-14.

7. Luks AM, McIntosh SE, Grissom CK, Auerbach PS, Rodway GW, Schoene RB, et al. Wilderness medical society consensus guidelines for the prevention and treatment of acute altitude illness. Wilderness Environ Med. 2010;21(2): 146-55. Available from:. https://doi.org/10.1016/j.wem.2010.03.002

8. Johnson TS, Fulco CS, Cymerman A, Trad LA, Larsen RF, Rock PB. Dexamethasone as prophylaxis for Acute Mountain sickness. Chest. 2007; 95(3):568-73.
9. Wu T, Liu J. Alcohol and aspirin in combination with dexamethasone causes gastrointestinal bleeding at high altitude. Wilderness Environ Med. 2006; 17(1):69-72.

10. Tang E, Chen Y, Luo Y. Dexamethasone for the prevention of acute mountain sickness: systematic review and meta-analysis. Int J Cardiol. 2014;173(2):133-8. Available from:. https://doi.org/10.1016/j.ijcard.2014.03. 019.

11. Ritchie ND, Baggott AV, Andrew Todd WT. Acetazolamide for the prevention of Acute Mountain sickness-a systematic review and metaanalysis. J Travel Med. 2012;19(5):298-307.

12. Zheng $C R$, Chen $G Z, Y u$ J, Qin J, Song P, Bian SZ, et al. Inhaled budesonide and oral dexamethasone prevent acute mountain sickness. Am J Med. 2014 127(10):1001-1009.e2. Available from: https://doi.org/10.1016/j.amjmed. 2014.04.012

13. Chen GZ, Zheng CR, Qin J, Yu J, Wang H, Zhang JH, et al. Inhaled budesonide prevents acute mountain sickness in young chinese men. J Emerg Med. 2015;48(2):197-206. Available from:. https://doi.org/10.1016/j. jemermed.2014.07.047

14. Berger MM, Macholz F, Sareban M, Schmidt P, Fried S, Dankl D, et al. Inhaled budesonide does not prevent acute mountain sickness after rapid ascent to 4559 m. Eur Respir J. 2017:50(3):1700982.

15. Lipman GS, Pomeranz D, Burns P, Phillips C, Cheffers M, Evans K, et al. Budesonide Versus Acetazolamide for Prevention of Acute Mountain Sickness. Am J Med. 2018;131(2):200.e9-200.e16. Available from:. https://doi. org/10.1016/j.amjmed.2017.05.034.

16. Wang $X$, Chen $H$, Li R, Fu W, Yao C. The effects of respiratory inhaled drugs on the prevention of acute mountain sickness. Med (United States). 2018; 97(32):1-7.

17. Li HJ, Zheng CR, Chen GZ, Qin J, Zhang JH, Yu J, Zhang EH, Huang L. Budesonide, but not dexamethasone, blunted the response of aldosterone to renin elevation by suppressing angiotensin converting enzyme upon high-altitude exposure. Journal of the Renin-Angiotensin-Aldosterone System. 2016;17(2):1470320316653867.

18. Liberati A, Altman DG, Tetzlaff J, Mulrow C, Gøtzsche PC, loannidis JPA, et al. The PRISMA statement for reporting systematic reviews and meta-analyses of studies that evaluate health care interventions: explanation and elaboration. J Clin Epidemiol. 2009;62(10):e1-34.

19. Roach RC, Bartsch P, Hackett PH, Olez O, Oelz O. The Lake Louise acute mountain sickness scoring system. Hypoxia Mol Med Proc 8th Int Hypoxia Symp Held Lake Louise, Canada, Febr 9-13, 1993 [Internet]. 1993; 272(February 2017):272-4. Available from: https://www.researchgate.net profile/Peter_Hackett/publication/277718910_The_Lake_Louise_Acute Mountain_Sickness_Scoring_System/links/58a71b8b92851cf0e3b96d5a/TheLake-Louise-Acute-Mountain-Sickness-Scoring-System.pdf.

20. Higgins JPT, Altman DG, Gøtzsche PC, Jüni $P$, Moher D, Oxman AD, et al. The Cochrane Collaboration's tool for assessing risk of bias in randomised trials. BMJ. 2011;343(7829):1-9.

21. JA ØJ, Thorsson L, Bisgaard H. Department. Lung deposition of inhaled drugs increases with age? [5] (multiple letters). Am J Respir Crit Care Med. 2000;162(5):1279.

22. Sharma G, Goodwin J. Effect of aging on respiratory system physiology and immunology. Clin Interv Aging. 2006;1(3):253-60 Available from: http:// www.ncbi.nlm.nih.gov/pubmed/18046878\%0Ahttp://www.pubmedcentral. nih.gov/articlerender.fcgi?artid=PMC2695176.

23. Bailey DM, Bärtsch $P$, Knauth M, Baumgartner RW. Emerging concepts in acute mountain sickness and high-altitude cerebral edema: from the molecular to the morphological. Cell Mol Life Sci. 2009;66(22): 3583-94.

24. Bartsch P, Bailey DM, Berger MM, Knauth M. Acute Mountain Sickness: Controversies and Advances. High Alt Med Biol. 2004:5(2):110-24.

25. Strapazzon G, Malacrida S, Vezzoli A, Cappello TD, Falla M, Lochner P, et al. Oxidative stress response to acute hypobaric hypoxia and its association with indirect measurement of increased intracranial pressure : a field study. Nat Publ Gr. 2016:(April):1-8. Available from:. https://doi.org/10.1038/ srep32426.

26. Sturdivant NM, Smith SG, Ali SF, Wolchok JC, Balachandran K. Acetazolamide mitigates astrocyte cellular edema following mild traumatic brain injury. Sci Rep. 2016:6(September):1-11. Available from:. https://doi.org/10.1038/ srep33330.

27. Faupel G, Reulen HJ, Müller D, Schürmann K. Dexamethasone in severe head injuries. Neurosurg Rev. 1979;2(3):105-11. 
28. Jha S. Cerebral edema and its management. Med J Armed Forces India. 2011;59(4):326-31. Available from:. https://doi.org/10.1016/S0377$1237(03) 80147-8$.

29. Roach RC, Hackett PH, Oelz O, Bärtsch P, Luks AM, Maclnnis MJ, et al. The 2018 Lake Louise Acute Mountain sickness score. High Alt Med Biol. 2018; 19(1):4-6 Available from: http://www.liebertpub.com/doi/10.1089/ham.2017. 0164

\section{Publisher's Note}

Springer Nature remains neutral with regard to jurisdictional claims in published maps and institutional affiliations.

Ready to submit your research? Choose BMC and benefit from:

- fast, convenient online submission

- thorough peer review by experienced researchers in your field

- rapid publication on acceptance

- support for research data, including large and complex data types

- gold Open Access which fosters wider collaboration and increased citations

- maximum visibility for your research: over $100 \mathrm{M}$ website views per year

At $\mathrm{BMC}$, research is always in progress.

Learn more biomedcentral.com/submissions 